\title{
LATE OLIGOCENE THOLEIITIC LAVA FROM KENANGA RIVER, TEGALOMBO PACITAN, EAST JAVA
}

\author{
Dian Novia Sartika ${ }^{1}$, I Wayan Warmada*1 ${ }^{*}$, Bhakti H. Harahap ${ }^{2}$, and Widiasmoro \\ Soewondo ${ }^{1}$ \\ ${ }^{1}$ Department of Geological Engineering, Gadjah Mada University, Yogyakarta, Indonesia \\ ${ }^{2}$ Pusat Survai Geologi, Bandung, Indonesia
}

\begin{abstract}
Watupatok Formation in Pacitan area consists of lava with basaltic composition and pillow structure. Kenanga river is only $5 \mathrm{~km}$ to southeast Watupatok village as type locality of this formation. Kenanga river's lava were varying from diabasic with paving surface and columnar joint structure to basaltic composition with pillow structure. Lava were found as effusive flow and dike with sandstone inclusion. In field observation, lava exhibits strong porphiritic to aphyric texture, with vesicular to amygdaloidal structure. Plagioclase as phenocryst has mediumsized (2-4 mm) surrounded by volcanic glass as groundmass. Petrographic analysis shows intersertal to hyalophilitic texture, consist of plagioclase, pyroxene and opaque minerals as phenocryst and also groundmass together with volcanic glass. Seconday minerals are quartz, zeolite and calcite. Geochemichal analysis results indicate a low $\mathrm{TiO}_{2}(0.8$ $0.9 \mathrm{wt. \% )}$, medium to high $\mathrm{Al}_{2} \mathrm{O}_{3}$ (14-17 wt.\%), high $\mathrm{Fe}_{2} \mathrm{O}_{3}$ (10-12 wt.\%) and low $\mathrm{Mg}$ value (Mg\#) (39-42). According to TAS and AFM diagram, the rocks is apparently to be basalt and tholeiitic island arc magma. While spidergram pattern of the trace elements shows relatively flat fo HREE and enriched pattern on LREE. Niobium element displays a depleted anomaly, indicated that the crust influences in parental magma, which is another characteristic
\end{abstract}

${ }^{*}$ Corresponding author: I W. WARMADA, Department of Geological Engineering, Faculty of Engineering, Gadjah Mada University, Jl. Grafika 2 Yogyakarta, 55281, Indonesia. E-mail: warmada@yahoo.com of magmatic island arc. Based on regional tectonic, the volcanic rocks from Late Oligocene in the area has relationship with subduction processes between Indo-Australia plate and Eurasian plate.

Keywords: Pillow structure, tholeiitic, lava, subduction

\section{Introduction}

Pacitan area are part of Southern Mountain (Van Bemmelen, 1949), with regional tectonic as transition zone in mesozoikum paleosubduction. It has Northeast-Southwest trend and Tertiary-Recent subduction with East-West trend (Purwanto et al, 1997). Volcaniclastic rocks were often found together with igneous rock such pillows lava flow as evidence of earliest magmatic event (Late Eocene - Early Miocene). The K-Ar dating of the pillows lava from Pacitan has Late Eocene (42.7 Ma) age. The pillows lava mostly aphyric with less then $5 \%$ microphenocrysts. Chemical analysis indicates basaltic and andesitic composition and the trace element pattern are relatively flat. It is a typical features for island arc tholeiitic (Soeria-Atmadja et al, 1991). This lava are belong to Besole Formation which has similiar age to Watupatok Formation.

This paper investigate characteristic and genesis of Kenanga river lava which is not to far from Watupatok village as typical location area. Data are taken by rock sampling and field observation, laboratory analysis including thin 
section and geochemical data using ICP-MS methods for selected rock samples.

\section{Geologic setting}

Watupatok Formation composed of volcaniclastic rock such as basalt pillow lava intercalated with sandstone, claystone and diatome (Samoedra et al, 1992). Regional structure has been happened in this area including sinistral strikeslip fault (Grindulu fault and Tegalombo fault) with NE-SW trend. North Pacitan area are part of fold hills geomorphological unit. Kenanga river area is a levee part lava hills and consist of some litholigical units including breccia, tuffaceous sandstone, diabasic lava and basaltic pillow lava unit (Figure 1). Breccia unit including polymic breccia and volcaniclastic breccia. The tuffaceous sandstone consists of fine sandstone, tuffaceous sandstone and tuff layers. Diabasic lava unit contains sandstone inclusion while basaltic pillows lava unit consists of basaltic pillows lava with hyaloclastic breccia.

\section{Mineralogy and petrography}

Petrographic analysis to certain rock sample from research area showing intersertal to vitrophyric texture (Figure 2). Commonly the phenocryst are plagioclase $\mathrm{An}_{10-15}-\mathrm{An}_{30-50}$ (oligoclase-andesine) and less pyroxene. Groundmass composed of mikrolite plagioclase, pyroxene, opaque minerals. Some sample performing secondary minerals such as calcite, zeolite and quartz as amygdaloids.

Plagioclase Petrographic analysis result varying sized of plagioclase, from $0.15-0.5 \mathrm{~mm}$ as groundmass, $0.5-3 \mathrm{~mm}$ as phenocryst. Plagioclase crystal displays prismatics to platty form, usually euhedra-subhedra, and also spongy cell (sieve-like texture). Which is an indication of solution melting processes or caused by pressure and or temperature changing that has relation to magma mixing (Hibbard, 1995).

Pyroxene Petrographic analysis result varying sized of pyroxene, from $0.2-0.5 \mathrm{~mm}$ as groundmass, $>0.5 \mathrm{~mm}$ as phenocryst. Pyroxene has granular and euhedral to subhedral form, and sometime as intergrowth with plagioclase. There are 2 type of pyroxene, the clinopyroxene including augite and pigeonite and the orthopyroxene were found abundant as groundmass. Pyroxene crystal structure forming an aggregate with angle $120^{\circ}$ on each side, indicated cumulate structure (Hibbard, 1995)

Opaque mineral Petrographic analysis conclude opaque minerals based on with brown color and high relief as microscopis characteristics. Generally, it was found as euhedral and granular form. Opaque minerals were recognized as magnetite, hematite and ilmenite. On some thin section, opaque mineras abundant is more than $10 \%$.

Volcanic glass Volcanic glass on Kenanga river lava as rock forming mineral, usually were found on vitrophyric, hyalophilitic and intersertal texture. Glass as groundmass were formed on hydrous condition such pillow lava was called to be palagonite (Williams et al, 1954), and characterized by yellow to brownish color, anhedra form usually as groundmass in some sample also as pore filling.

Secondary minerals Secondary minerals as pore filling such as quartz, zeolite and calcite. They usually anhedral. Quartz has white first order color, zeolite forms spherulite and calcite has mozaic structure. The abundant of secondary mineral depend on pores on the rock.

\section{Geochemistry}

\subsection{Major elements}

Major oxide composition data has collected from 3 rock samples, represented for pillow lava (TK0105), columnar joint lava (TK0205) and paving surface lava (TK0305). As comparison data, were used data from former research in Pacitan area who is belong to Priadi \& Sucipta (1998). Those three sample has containing $\mathrm{SiO}_{2}$ as Le Maitre diagram classification (Figure 3) and concluded as basalt (46.8-50.65 wt.\%), 
Distribution map of lava in Kenanga river

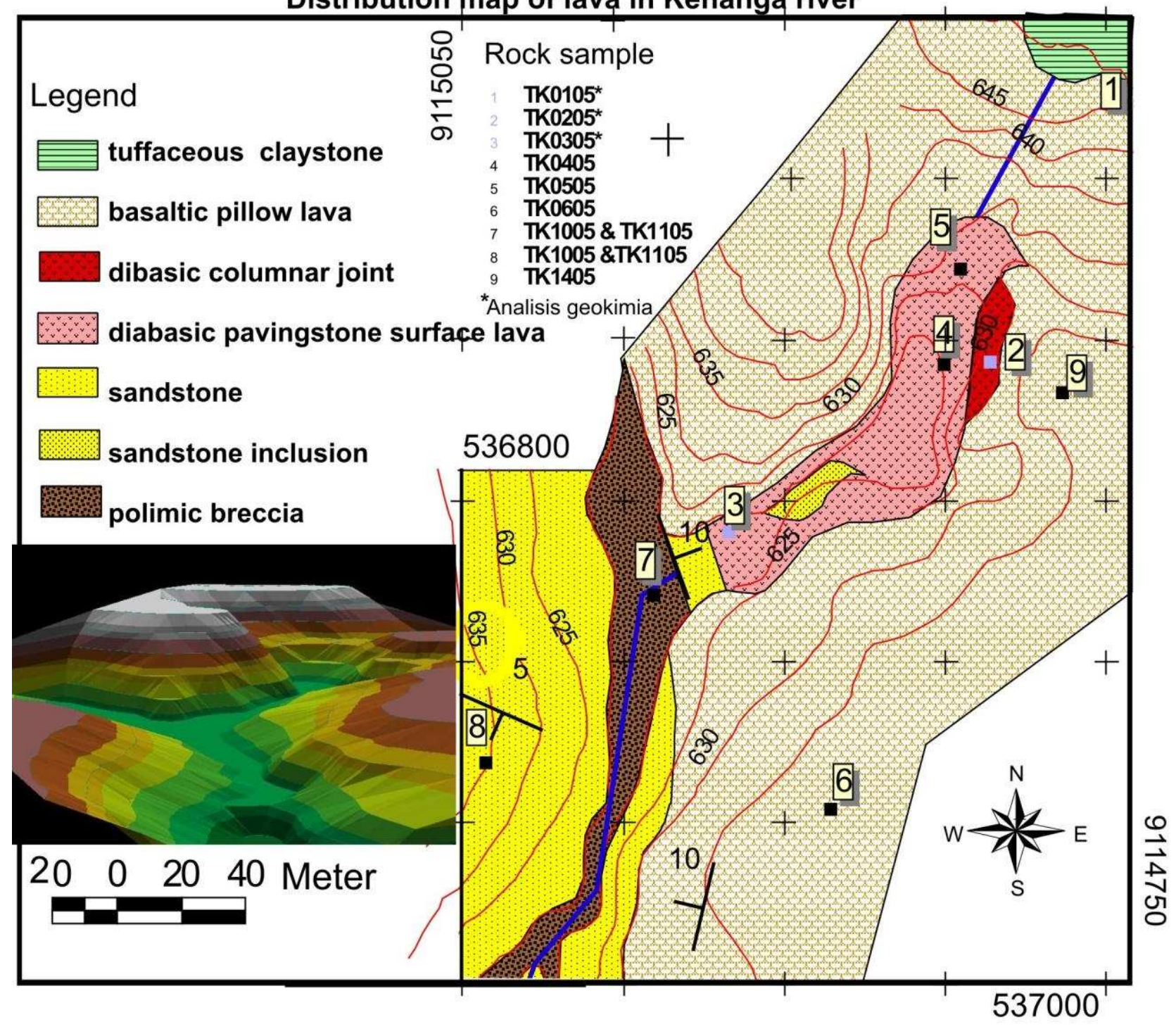

Figure 1: Distribution of Kenanga River lava 
A

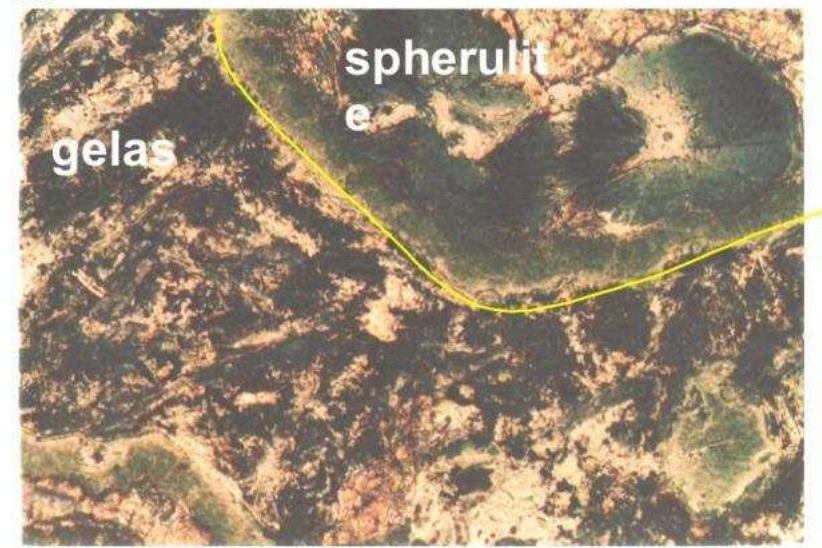

B

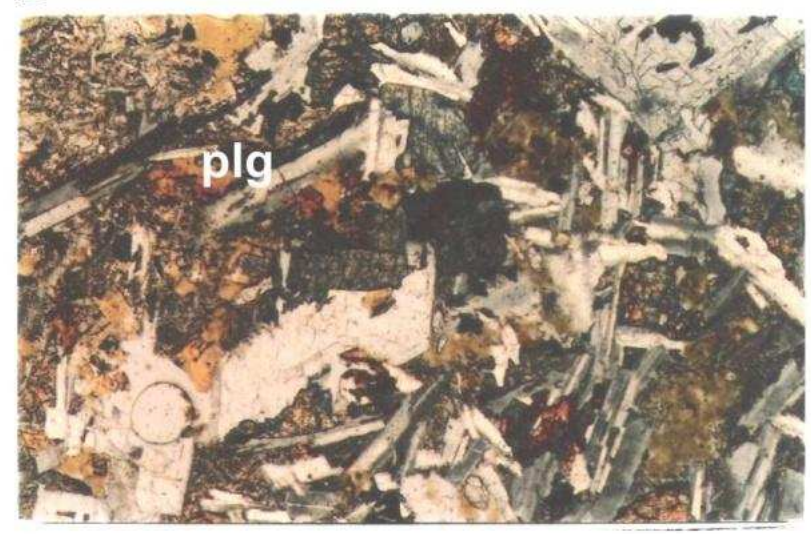

$\mathrm{C}$

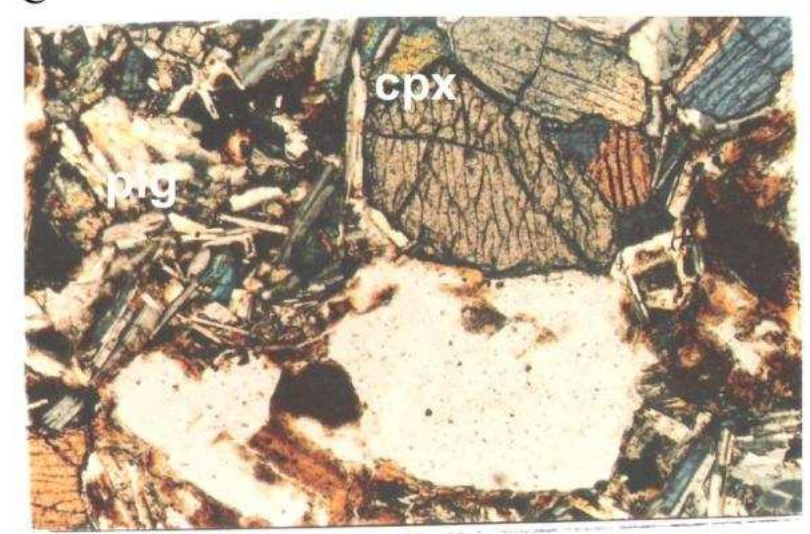

$\mathrm{D}$

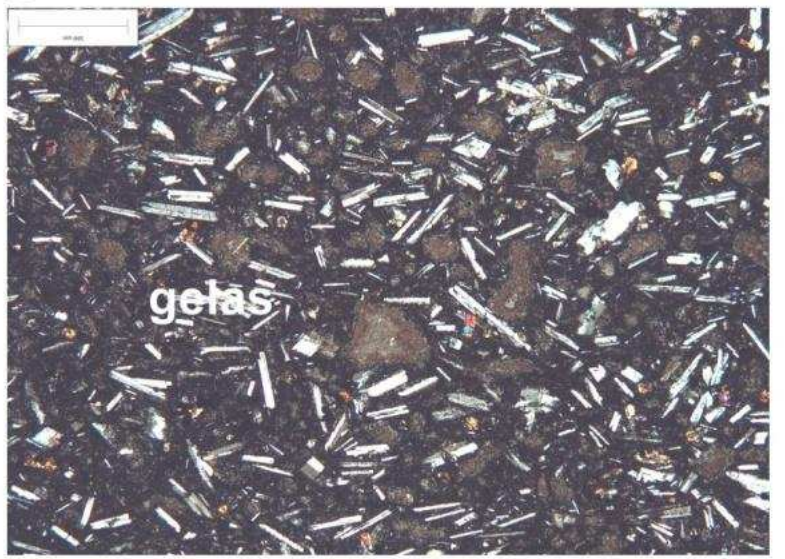

E

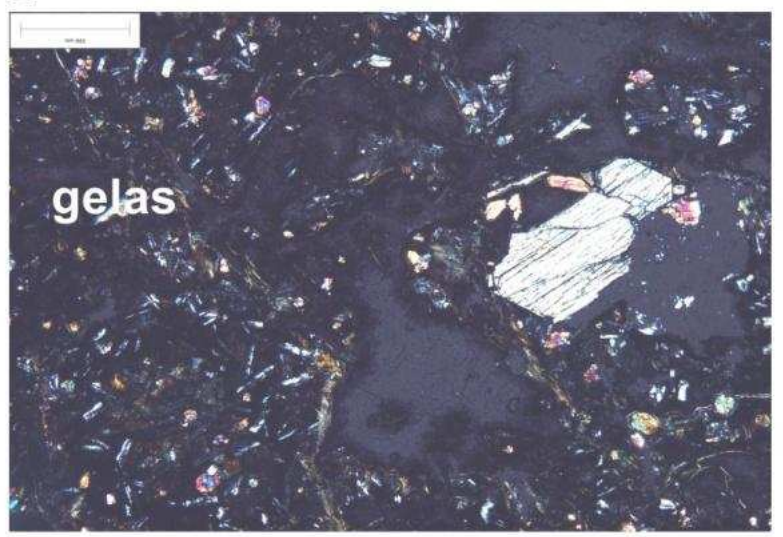

$\mathrm{F}$

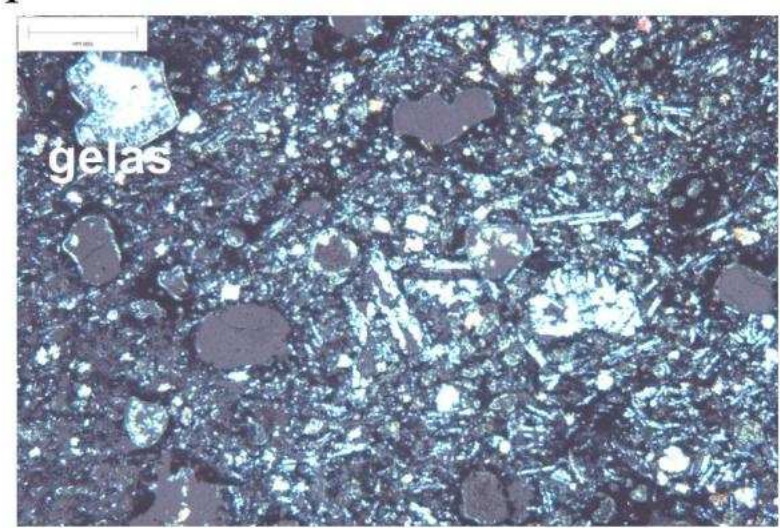

Figure 2: A) Pillow lava (TK0105), B) Columnar joint lava (TK0205), C) Pavingstone, D) surface lava (TK0305), D) Dike (TK0505), E) Hyaloclastic breccia fragment (TK1605), F) Hyaloclastic breccia matrix (TK1705) 


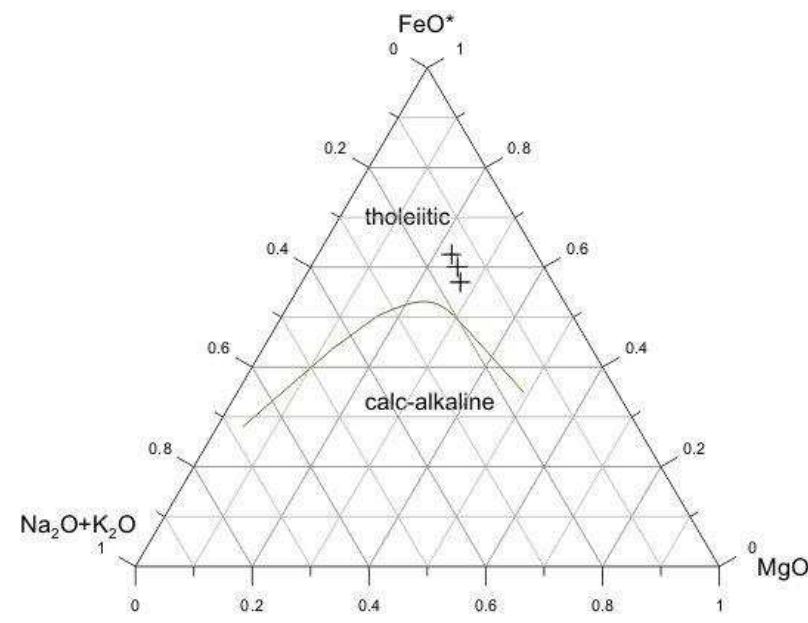

Figure 4: AFM diagram

while $\mathrm{TiO}_{2}<1.2$ wt.\% (low) and $\mathrm{Fe}_{2} \mathrm{O}_{3}$ 10-12 wt.\% (high). According to Le Maitre (1989), classification based on percentage of $\mathrm{SiO}_{2}$ basalt are contain $43-53$, basalt-andesitic 53-56, andesite 56-63 and rhyolite $>63$ percentage of $\mathrm{SiO}_{2}$. Based on AFM diagram (Figure 4), rock series of Kenanga river lava was recognized has differentiated tholeiitic and concluded as basalt. This condition indicates Fe-rich happened from early stage of crystallization.

Harker variation diagram (Figure 5) with include the data from Priadi and Sucipta (1998) as comparative data display $\mathrm{TiO}_{2}, \mathrm{CaO}$ and $\mathrm{Fe}_{2} \mathrm{O}_{3}$ trend which form negative correlation line during the $\mathrm{SiO}_{2}$ rise. This has become an evidence of plagioclase and magnetite as major fractionated on magma evolution (Wilson, 1989). Early magmatic temperature may discovered from normative contain of anorthite, albite and orthoclase using Tertiary diagram from Yoder et al (1957 in Deer et al., 1966). Normative calculations conclude that magmatic temperature ranges from 1050 to $1100^{\circ}$. Tectonic setting diagram from Mullen (1983 vide Rollinson, 1993) based on $\mathrm{TiO}_{2}, \mathrm{MnO}$ and $\mathrm{P}_{2} \mathrm{O}_{5}$ composition of those 3 samples, conclude as Island Arc Tholeiitic (Figure 6).

\subsection{Trace and rare earth elements}

On spidergram plotting element to find tectonic setting of Kenanga river's lava was based on normalized pattern of elements with primitive

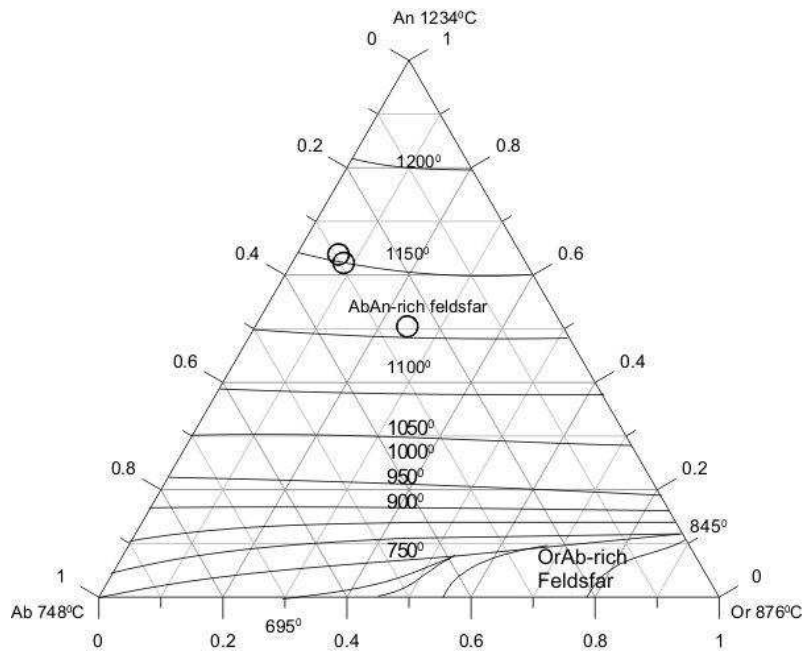

Figure 6: Yoder diagram

mantle based on Sun and McDonough (1989). Primitive mantle normalized was choosen since rock from Kenanga river has been altered and from Late Oligocene (Jenner, 1996). Rock classification based on element contain using Floyd and Winchester (1977 in Pearce, 1996) classification define the rock as subalkaline basalt.

Spidergram pattern for trace element performing a random/uneven on LREE that indicate contamination/richness during crystallization processes, while the HREE displays flat pattern. This pattern was commonly found in initiary collision zone. On REE diagram, the pattern showing a flat correlation for all element, this is has become an indication of the same magma source for those 3 samples. Beside those pattern, niobium give a negative anomaly (down peak) with the value less than 10, is a typical character for island arc tectonic setting and crust influence during magma melting (Wilson, 1989).

\section{Discussion and conclusions}

Based on mineralogy and chemical characteristics, Kenanga river lava as effusive lava flow which has minerals composition consist of plagioclase (labradorite), pyroxene and glass material in abundant, with less opaque minerals. Color index as another characteristic conclude as intermediet rock, but the texture is vitrophyric to intersertal and contain $\mathrm{SiO}_{2}$ 46.8-50.65 


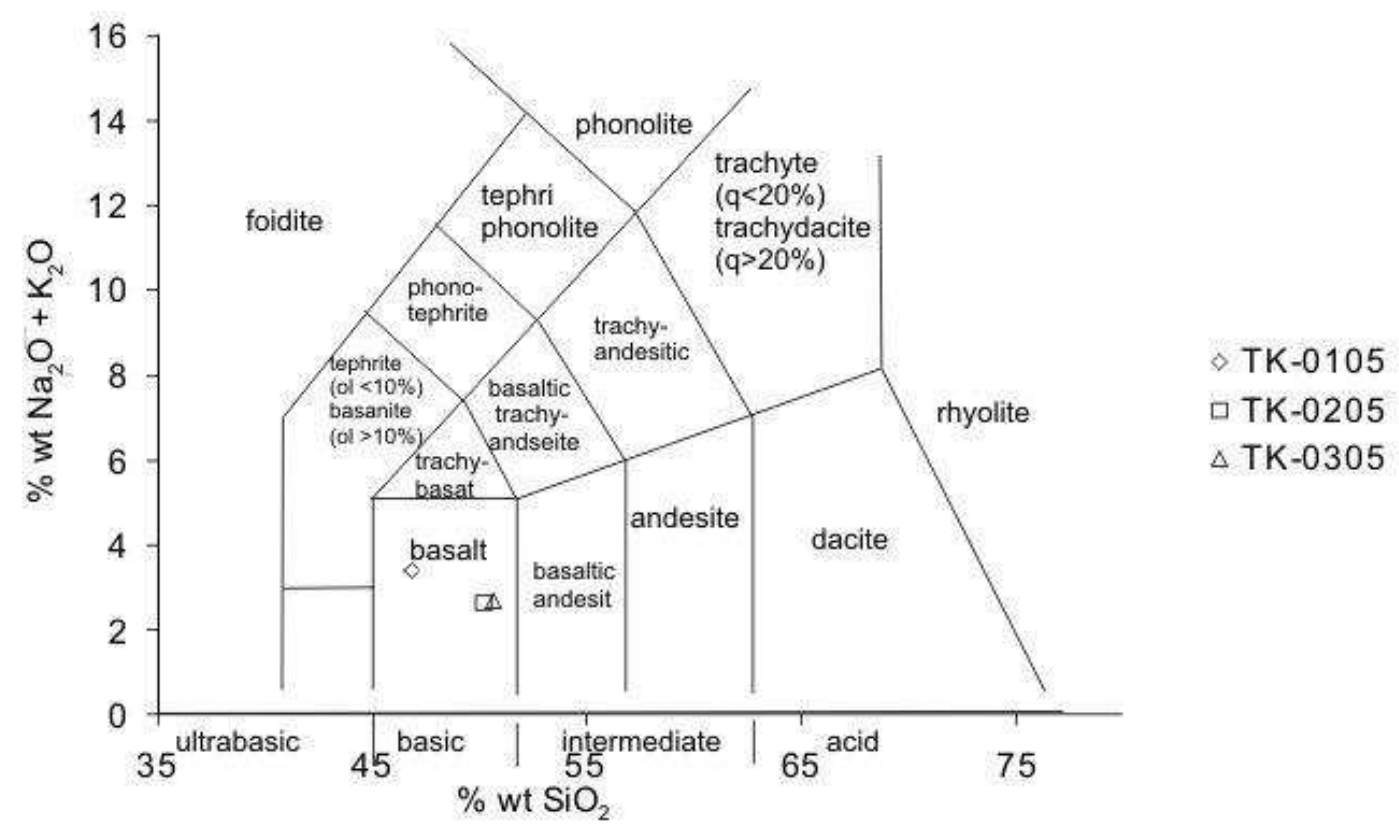

Figure 3: TAS diagram of selected samples according Le Maitre (1989)

wt.\%. Therefore it difine as basalt to diabas (Williams et al., 1954; Le Maitre, 1989) and classification based on element from Winchester and Floyd (1977) fall as basalt with subalkalin affinities. Magmatic source are tholeiitic series, with medium $\mathrm{K}$ content and has medium differentiation index. This was represented by low $\mathrm{TiO}_{2}(1.2 \% \mathrm{wt})$, high $\mathrm{Fe}_{2} \mathrm{O}_{3}$ compared with calcalkaline type which is rich in $\mathrm{K}$ but has low $\mathrm{MgO}$ and $\mathrm{Fe}_{2} \mathrm{O}_{3}$.

Magmatic temperature at the beginning is quite high (above $1050^{\circ} \mathrm{C}$ ) confirming basic magma type. Tectonic setting based on tholeiitic magma type and $\mathrm{Nb}$ negative anomaly show that the magma were from subduction zone related to oceanic crust on island arc. Major oxide variation diagram displays magmatic crystalization processes has both melting fractionation and crystalization fractionation mechanisme, which is displayed from negative correlation line for $\mathrm{MgO}, \mathrm{TiO}_{2}, \mathrm{CaO}$ and $\mathrm{Fe}_{2} \mathrm{O}_{3}$. This diagram showing the same result to petrographic analysis which form plagioclase, pyroxene (clinopyroxene including pigeonite and augite, orthopyroxene) and opaque minerals.

During the liquid-crystal magmatic differentiation processes, porphyritic texture may hap- penend as a result of segregation and cumulate processes (Figure 3). Porphyritic texture also represented that magma at least has 2 stage crystalization. Plagioclase as phenocryst formed first at the high temperature $\left(>1100^{\circ} \mathrm{C}\right)$, when the temperature start to cooling down pyroxene and Fe rich minerals such opaque minerals start to formed, during this formation $\mathrm{SiO}_{2}$ contain slowly decrease (Gill, 198?).

\section{References}

Best, M. J. (1982) Igneous and Metamorphic Petrology, W. H Freeman Company, San Fransisco.

Deer, W. A., Howie, R.A., Zussman, J. (1966) An Introducton to the Rock Forming Minerals, Commonwealth Printing Press, Hongkong.

Hibbard, M. J. (1995) Petrography to Petrogenesis, Prentice-Hall, New Jersey.

Jenner, G.A. (1996) Trace element geochemistry of igneous rocks: geochemical nomenclature and analytical geochemistry, dalam Wyman, D.A. (ed) Trace Element Geochemistry of Volcanic Rocks: Application for Massive Sulphide Exploration, Geological Association of Canada, Short Course Notes, v. 12, p. 51-77.

McPhie, J., Doyle, M., Allen, R. (1993) Volcanic Texture, Tasmanian Government Printing Office, Tasmania. 

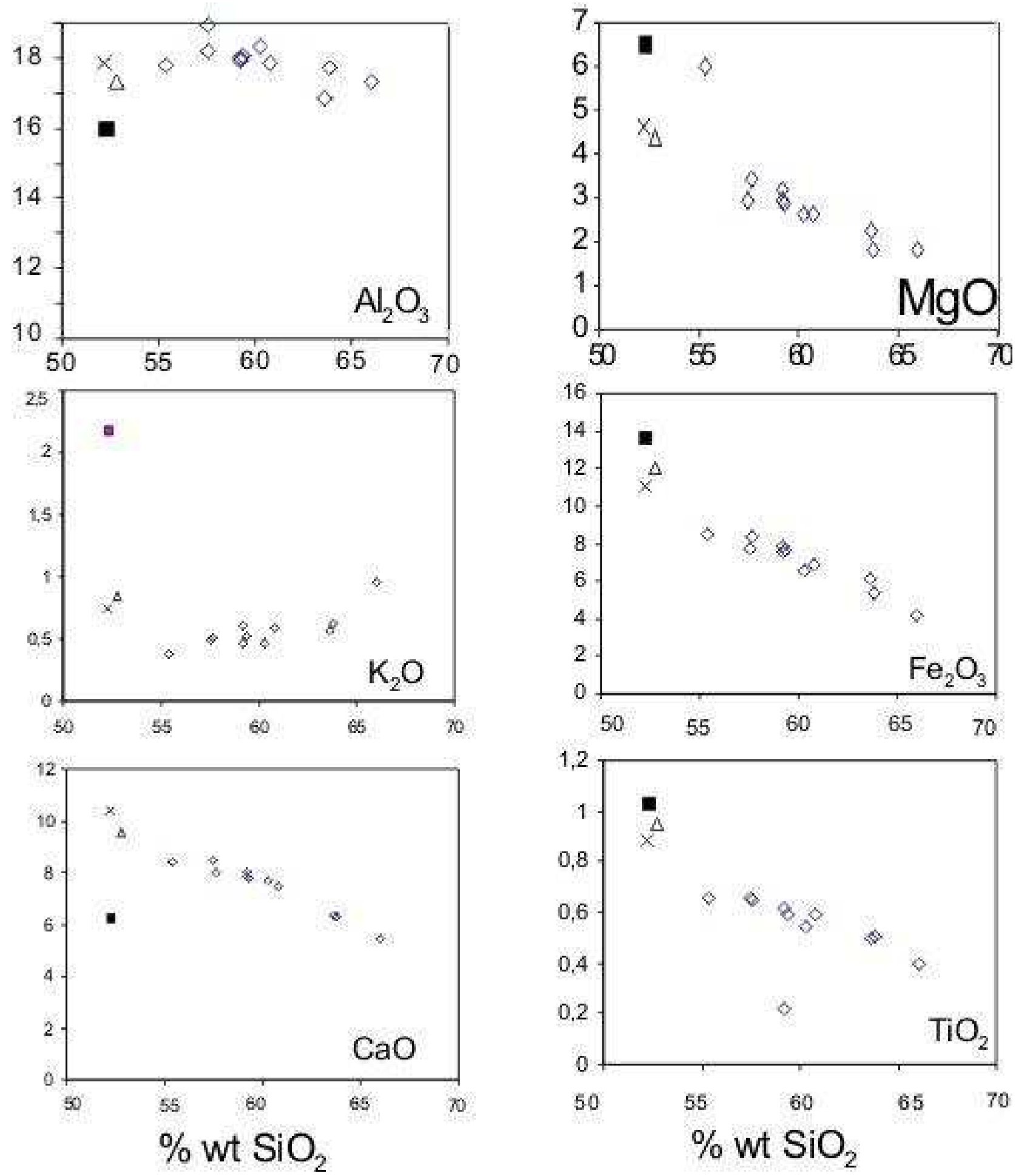

$\checkmark$ Priadi\&Sucipta $(1998)=$ TK-0105 $\triangle$ TK-0205 $\times$ TK-0305

Figure 5: Harker variation diagram 
Priadi, B and Sucipta, I G. B. (1998) Tholeitic to Alkaline Cenozoic Magmatism in East Java, Indonesia, Prosiding PIT XXVII, IAGI, Yogyakarta, pp 3-263-36

Purwanto, H.S., Abdullah, C.I., Noeradi, D. (1997) Rekonstruksi tegasan purba berdasarkan data struktur mesoskopik, di daerah Pacitan dan sekitarnya, Jawa Timur, Prosiding PIT XXVI, Jakarta. pp 443-452.

Pearce, J.A. and Cann, J.R. (1973) Tectonic setting of basic volcanic rocks determined using trace element analyses, Earth And Planetary Science Letters, North-Holland Publishing Company.

Rollinson, H. (1993) Using Geochemichal Data: evaluation, presentation, interpretation, Longman Singapore Publishers, Singapore.

Samodra, S., Gafoer, Tjokrosaputra, S. (1992) Peta Geologi Lembar Pacitan, Direktorat Geologi Bandung, skala 1 : 100.000 .
Sampurno and Samodra (1991) Geologi lembar Ponorogo, Jawa, Direktorat Geologi Bandung, skala 1: 100.000 .

Soeria-Atmadja, R., Maury., R.C., Bellon, H., Pringgoprawiro, H., Polve, M., Priadi, B. (1994) Tertiary magmatic belts in Java, dalam Journal of Southeast Asian Earth Sciences, Pergamon Press Ltd, Great Britain. v 9, pp 13-27.

Sun, S. and McDonough, W.F. (1989) Chemical and isotopic systematics of oceanic basalts: implication for mantle composition and processes dalam Sounders and Norry, (ed), Magmatism in the Ocean Basins, Geological Society Special Publication No.42, pp. 313-345.

Williams, H., Turner, F.J., Gilbert, C.M. (1954) Petrography an Introduction to the Study of Rocks in Thin Sections, WH Freeman and Company, San Fransisco.

Wilson, M. (1989) Igneous Petrogenesis, Harper Collins Academic, London. 